Far Eastern Entomologist

\begin{tabular}{lll}
\hline Number 427: 25-28 & ISSN 1026-051X (print edition) & March 2021 \\
\hline
\end{tabular}

https://doi.org/10.25221/fee.427.3

http://zoobank.org/References/B3E9438D-7EFA-4FCD-B432-17C6190CEDA0

\title{
NEW FOR THE RUSSIAN FAUNA SPECIES OF THE FAMILIES EREBIDAE AND NOCTUIDAE (LEPIDOPTERA)
}

\author{
E. S. Koshkin ${ }^{1, *)}$, B. Benedek ${ }^{2)}$, V. A. Golovizin ${ }^{3)}$
}

1) Institute of Water and Ecology Problems of the Far Eastern Branch of the Russian Academy of Sciences - branch of the Khabarovsk Federal Research Center of the Far Eastern Branch of the Russian Academy of Sciences, Dikopoltsev St., 56, Khabarovsk, 680000, Russia.*Corresponding author,E-mail: ekos@inbox.ru

2) H-2045 Törökbálint, Árpád u. 53, Hungary.E-mail: benedekia@gmail.com

3) Svetlogorskaya St., 35-133, Krasnoyarsk, 660125, Russia. E-mail: g-vadim-krsk@ yandex.ru

Summary. Three noctuid species are found in Russia for the first time, of them two species, Bertula spacoalis (Walker, 1859) (Erebidae) and Euplexidia angusta Yoshimoto, 1987 (Noctuidae), are new for Primorskii krai, and Orthosia aoyamensis (Matsumura, 1926) (Noctuidae) - for Sakhalin Island.

Key words: moths, Herminiinae, Noctuinae, fauna, new records, Russian Far East.

Е. С. Кошкин, Б. Бенедек, В. А. Головизин. Новые для фауны России виды семейств Erebidae и Noctuidae (Lepidoptera) // Дальневосточный энтомолог. 2021. N 427. С. 25-28.

Резюме. Впервые для фауны России приводятся три вида совкообразных чешуекрылых. Два вида - Bertula spacoalis (Walker, 1859) (Erebidae) и Euplexidia angusta Yoshimoto, 1987 (Noctuidae), найдены в Приморском крае, a Orthosia aoyamensis (Matsumura, 1926) (Noctuidae) впервые указывается с острова Сахалин.

\section{INTRODUCTION}

The Russian Far East fauna of Noctuid moths [former family Noctuidae (s. 1.), nowadays divided into Noctuidae (s. str.), Erebidae (without Lymantriinae and Arctiinae), Euteliidae, and Nolidae] includes 991 species (Kononenko, 2016 a-d) or 986 species (Matov, 2019 a, b; Matov et al., 2019 a, b). Furthermore, after the publication of these books, four additional species has been recorded from this territory (Koshkin, 2020; Koskin \& Pekarsky, 2020; Rybalkin, 2020).

Present paper provides data about first finds of three species of Noctuid moths in Russia. Thus, fauna of the Russian Far East approaches a thousand species.

The moths were collected by light traps. Studied specimens are deposited in the collections of E.S. Koshkin [EK] and B. Benedek [BB]. 


\section{NEW RECORDS \\ Family Erebidae \\ Subfamily Herminiinae}

Bertula spacoalis (Walker, 1859)

Figs 1, 4

Bleptina spacoalis Walker, 1859: 872 (type locality: North China).

MATERIAL. Russia: Primorskii krai, Khasan District, Zarubino village, 42³9' N, $131^{\circ} 04^{\prime}$ E, 23. VII 2020, 1ㅇ, leg. V. Golovizin [EK].

DISTRIBUTION. Russia (new record): Primorskii krai. - Japan: Hokkaido, Honshu, Shikoku, and Kyushu Islands; North and South Korea; China (Inoue et al., 1982; Kononenko et al., 1998).

REMARKS. Bleptina spacoalis differs from the similar B. bistrigata (Staudinger, 1888) (also distributed in the southern part of the Russian Far East) by a wavy medial line on forewing and absence of reniform spot. The specimen of B. spacoalis collected in Khasan District is presumably a migrant from more southern regions.

\section{Family Noctuidae}

Subfamily Noctuinae

Orthosia aoyamensis (Matsumura, 1926)

Figs 2, 5

Monima aoyamensis Matsumura, 1926: 13 (type locality: Japan: Hokkaido, Aoyama near Kutchan, and Sapporo).

MATERIAL. Russia: Sakhalinskaya oblast, Sakhalin Island, near Yuzhno-Sakhalinsk, 5 $\mathrm{km}$ NE of Novo-Aleksandrovsk, $47^{\circ} 05^{\prime} \mathrm{N}, 142^{\circ} 46^{\prime} \mathrm{E}, 10-25 . \mathrm{V} 2019,5 \partial^{\lambda}$, leg. O. Kuporosov [BB].

DISTRIBUTION. Russia (new record): Sakhalin Island. - Japan: Hokkaido, Honshu, Shikoku, and Kyushu Islands (Matsumura, 1926; Inoue et al., 1982).

REMARKS. Externally Orthosia aoyamensis resembles O. incerta (Hufnagel, 1766) but with noticeable basal, antemedial and postmedial lines on forewings; medial field is usually darker than ground colour of forewings. In male genitalia ventral margin of cucullus with strong concavity and without noticeable pollex. Most likely in the southern part of Sakhalin O. aoyamensis is an autochthonous species and its late discovery here can be explained by the poor knowledge of the spring aspect of Noctuidae fauna of this territory.

\section{Euplexidia angusta Yoshimoto, 1987}

Figs 3, 6

Euplexidia angusta Yoshimoto, 1987: 97 (type locality: Japan, Kyushu, Fukuoka, Mt. Hikosan).

MATERIAL. Russia: Primorskii krai, Shkotovo District, Anisimovka village, $43^{\circ} 10^{\prime} \mathrm{N}$, $132^{\circ} 48^{\prime}$ E, 29.VI 2019, 10, leg. V. Golovizin [EK].

DISTRIBUTION. Russia (new record): Primorskii krai. - South Korea; Japan: Hokkaido, Honshu, Shikoku, Kyushu, Ryukyu, Tsushima, and Yakushima Islands; Taiwan (Inoue et al., 1982; Yoshimoto, 1987; Kononenko et al., 1998; Eda \& Shikata, 2011). 
REMARKS. The genus Euplexidia Hampson, 1896 consists of 21 species from Southeast Asia (Gyulai \& Saldaitis, 2014). A single species, E. angusta, formerly identified as Euplexia literata (Moore, 1882) by Inoue et al. (1982), is distributed in South Korea and Japan. A specimen collected in the southern part of Primorskii krai is most likely a migrant and could have flown with winds from the southern part of the Sea of Japan basin.
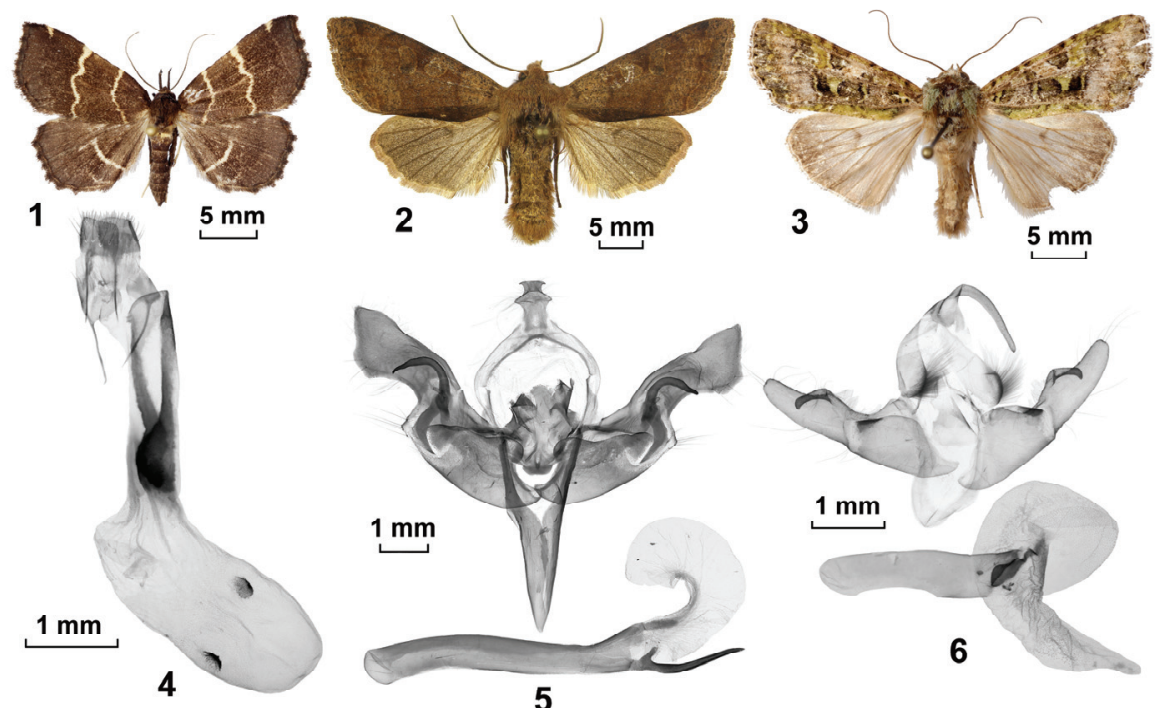

Figs 1-6. Habitus (1-3) and genitalia (4-6) of Noctuid moths. 1, 4 - Bertula spacoalis (Walker, 1859), female from Primorskii krai; 2, 5 - Orthosia aoyamensis (Matsumura, 1926), male from Sakhalin Island; 3, 6 - Euplexidia angusta Yoshimoto, 1987, male from Primorskii krai.

\section{ACKNOWLEDGEMENTS}

Authors would like to express their sincere thanks to Balázs Tóth (Budapest, Hungary) for the imago and genitalia photographs of Orthosia aoyamensis and to O.A. Kuporosov (Yuzhno-Sakhalinsk, Russia) for collected material. Authors are also grateful to E.V. Novomodny (Khabarovsk, Russia) for the opportunity to work with Japanese books from his library.

\section{REFERENCES}

Eda, K. \& Shikata, K. 2011. Xyleninae. P. 88-104, 323-367. In: The Standard of Moths in Japan. Vol. II. Tokyo. [In Japanese]

Kononenko, V.S. 2016a. Family Erebidae. P. 340, 364-399. In: Beljaev, E.A., Ponomarenko, M.G. \& Shabalin, S.A. (Eds). Annotated catalogue of the insects of Russian Far East. Volume II. Lepidoptera. Dalnauka, Vladivostok. 812 pp. [In Russian]

Kononenko, V.S. 2016b. Family Euteliidae. P. 399. In: Beljaev, E.A., Ponomarenko, M.G. \& Shabalin, S.A. (Eds). Annotated catalogue of the insects of Russian Far East. Volume II. Lepidoptera. Dalnauka, Vladivostok. 812 pp. [In Russian] 
Kononenko, V.S. 2016c. Family Nolidae. P. 399-408. In: Beljaev, E.A., Ponomarenko, M.G. \& Shabalin, S.A. (Eds). Annotated catalogue of the insects of Russian Far East. Volume II. Lepidoptera. Dalnauka, Vladivostok. 812 pp. [In Russian]

Kononenko, V.S. 2016d. Family Noctuidae. P. 408-510. In: Beljaev, E.A., Ponomarenko, M.G. \& Shabalin, S.A. (Eds). Annotated catalogue of the insects of Russian Far East. Volume II. Lepidoptera. Dalnauka, Vladivostok. 812 pp. [In Russian]

Gyulai, P. \& Saldaitis, A. 2014. A new species of Euplexidia Hampson, 1896 (Lepidoptera: Noctuidae) from Vietnam. Esperiana, 19: 181-185.

Inoue, H., Sugi, Sh., Kuroko, H., Moriuti, S. \& Kawabe, A. 1982. Moths of Japan. Vol. I. \& II. Tokyo: Kodansha Co. Ltd. P. 1-966. P. 1-552, 392 pls. [In Japanese]

Kononenko, V.S., Ahn, S.-B. \& Ronkay, L. 1998. Illustrated catalogue of Noctuidae in Korea (Lepidoptera). In: K.T. Park (ed.): Insects of Korea [3]. KRIBB \& CIS, Junghaeng-Sa, Seoul. 507 pp.

Koshkin, E.S. 2020. The first reliable record of a little-known species Orthosia ariuna Hreblay, 1991 (Lepidoptera, Noctuidae) from the Far East of Russia. Amurian Zoological Journal, 12(3): 286-292. DOI: 10.33910/2686-9519-2020-12-3-286-292 [In Russian]

Koshkin, E.S. \& Pekarsky, O. 2020. Victrix svetlanae sp. n., a new species of Bryophilinae (Lepidoptera, Noctuidae) from Far East of Russia. Zootaxa, 4750 (4): 585-590. DOI: 10.11646/zootaxa.4750.4.9

Matov, A.Yu. 2019a. Family Euteliidae. P. 317. In: Sinev, S.Yu. (Ed.). Catalogue of the Lepidoptera of Russia. 2nd edition. Zoological Institute RAS, St. Petersburg. 448 pp. [In Russian]

Matov, A.Yu. 2019b. Family Nolidae. P. 317-319. In: Sinev, S.Yu. (Ed.). Catalogue of the Lepidoptera of Russia. 2nd edition. Zoological Institute RAS, St. Petersburg. 448 pp. [In Russian]

Matov, A.Yu., Kononenko, V.S. \& Sviridov, A.V. 2019a. Family Erebidae. P. 305-316. In: Sinev, S.Yu. (Ed.). Catalogue of the Lepidoptera of Russia. 2nd edition. Zoological Institute RAS, St. Petersburg. 448 pp. [In Russian]

Matov, A.Yu., Kononenko, V.S. \& Sviridov, A.V. 2019b. Family Noctuidae. P. 320-370. In: Sinev, S.Yu. (Ed.). Catalogue of the Lepidoptera of Russia. 2nd edition. Zoological Institute RAS, St. Petersburg. 448 pp. [In Russian]

Matsumura, S. 1926. New species of Noctuidae from Japan and Formosa. Insecta Matsumurana, 1(1): 1-17

Rybalkin, S.A. 2020. New data on Lepidoptera of Kuril Islands. Far Eastern Entomologist, 401: 18-24. DOI: 10.25221 fee.401.4

Walker, F. 1859. List of the Specimens of Lepidopterous Insects in the Collecton of the British Museum. Part XIX. - Pyralides. London: Printed by Edward Newman. P. 799-1036.

Yoshimoto, H. 1987. Notes on the Genus Euplexidia Hampson, with descriptions of four new species and one new subspecies (Lepidoptera, Noctuidae, Amphipyrinae). Tyo to Ga, 38(2): 93-105.

(C) Far Eastern entomologist (Far East. entomol.) Journal published since October 1994. Editor-in-Chief: S.Yu. Storozhenko

Editorial Board: A.S. Lelej, S.A. Belokobylskij, M.G. Ponomarenko, V.A. Mutin, E.A. Beljaev, E.A. Makarchenko, A.V. Gorochov, T.M. Tiunova, M.Yu. Proshchalykin, S.A. Shabalin, V.M. Loktionov

Address: Federal Scientific Center of the East Asia Terrestrial Biodiversity (former Institute of Biology and Soil Science), Far East Branch of the Russian Academy of Sciences, 690022, Vladivostok-22, Russia.

E-mail: storozhenko@biosoil.ru web-site: http://www.biosoil.ru/fee 